\title{
THE QUALITY OF ENTREPRENEURIAL ENVIRONMENT AS A FACTOR OF FOREIGN DIRECT INVESTMENTS INFLOWS
}

\author{
DOI: 10.12776/QIP.V17I2.199
}

\author{
PETER KUZMIŠIN, ALŽBETA ŠIŠKOVÁ
}

\section{INTRODUCTION}

FDI flows in 2013 are expected to remain close to the 2012 level with an upper range of $\$ 1.45$ trillion - a level comparable to the pre-crisis average of 20052007. As macroeconomic conditions are improved and investors regain confidence in the medium term, TNCs may convert their record levels of cash holdings into new investments. FDI flows may reach the level of \$1.6 trillion in 2014 and $\$ 1.8$ trillion in 2015. However, significant risks to this growth scenario remain. Factors such as structural weaknesses in the global financial system, the possible deterioration of the macroeconomic environment, and significant policy uncertainty in areas crucial for investor's confidence might lead to a further decline in FDI flows (Zhan, 2013).

Entrepreneurial environment (EE) of every country was formed under the influence of certain specific conditions and occurrences resulting in the differences among entrepreneurial environments of the world. Significance of these differences increases in the context of globalization, liberalization of crossborder trade, high mobility of capital, transnational corporations, foreign direct investment (FDI) flows and the fight for foreign investors. Competitiveness is the factor connecting these terms.

Countries compete with each other for resources, capital, technological and informational transfers that come into the country together with foreign investors, which are usually transnational corporations (TNC). They are business entities different from domestic firms by the fact that foreign entities can choose a host country. This implies that they make decidions mainly according to quality of entrepreneurial environment of a country as a location for their investments. It is one of the key reasons why it is important to examine and identify the quality of entrepreneurial environment of a country.

Slovakia is relatively small and open economy which, together with the existing sector structure, means that in large extent it is dependent on foreign direct 
investments. What barriers can reduce FDI inflows? Which of them actually are able to discourage potential investors? Which ones should government monitor and mitigate? We will try to find answers on these questions in this paper.

The main objective of this study is to identify barriers of the Slovak entrepreneurial environment (EE), examine their correlation with FDI and on that base identify those barriers which removal would have a real impact on increasing attractiveness of Slovakia to foreign investors. The different stages are:

1) to identify barriers of the Slovak entrepreneurial environment in context of the V4 countries according to Doing Business;

2) to examine correlation of identified barriers and foreign direct investments. As a selective statistical set, the states chosen for testing are placed in the top 25 places of FDI Confidence Index (economies with the highest FDI inflows in period 2005 - 2010). Based on testing we will identify these barriers which removal would have a real impact on increasing attractiveness of Slovakia to foreign investors;

3) to determine relevant time period during which foreign direct investments are able to react to changes in conditions of entrepreneurial environment.

\section{THEORETICAL SOLUTIONS}

\subsection{Entrepreneurial environment as one of the factors of competitiveness}

There are many definitions of the entrepreneurial environment in economic literature according to which an entrepreneurial environment is the factor by which the economy enters into competition for investor or customer, and where they decide and choose an environment providing them the best conditions for doing business. An effort to create a business environment of the highest quality arises from the background of the concept of economy's competitiveness. There are many listed or other related topics from the field of entrepreneurial environment including considerations of regulatory environment (Lingreen and Hingley, 2003), effectiveness of supply chain involving technological progress (Hobbs and Young, 2000; Frolich and Westbrook, 2001), analysis of socioeconomic factors influencing behaviour of consumer (Hobbs and Young, 2000), emphasis on the need to be globally competitive (Folkerts and Koehorst, 1998) and increase of responsibility for the whole chain and product traceability (Rademakers and Knight, 1998; Wilson and Clarke, 1998).

From the perspective of strategic decision literature identifies (Dess and Beard, 1984; Ward et. al, 1995) four dimensions that together form the entrepreneurial environment: 
- Rate of dynamic refers to the speed and predictability of changes by organization in the field of environment.

- Complexity includes a number of skills in the organization.

- Variety is related to the extent to which organization meets with diffuse or homogeneous conditions.

- Responsiveness refers to how far, in terms of competitive pressures, organizations and their growth within the frame of EE are supported.

Viturka (2010), based on the Porter's microeconomic theory of competitiveness ${ }^{1}$, focuses on quality of regional entrepreneurial environment through four groups of factors:

1) Input factors (supply of production factors).

2) Demand factors (with attention on domestic demand).

3) Factors generated by presence of related and supporting industries (links to the division of labour and economic integration).

4) Factors generated by strategies and competitive nature of enterprises (links to the local investment environment and local policy).

According to Kuzmišinová (2009) business sector (micro) is a determining source of competitiveness at all levels of market economy, because it has an important role in the process of managing competitive pressures of market forces. Chi et al. (2009) paid attention to the structure of supply chain (SSC), while he suggested that SSC should be based on the specialty of entrepreneurial environment and is consistent with competitive priorities, on which the company is focused. Besides he expects significant causal relationship between SSC and entrepreneurial environment and between business competitive priorities and SSC. In final testing he assumes that there is a significant causal relationship among performance of the company and coordination of entrepreneurial environment, company's competitive priorities and the structure of its supply chain.

\subsection{Foreign direct investment and entrepreneurial environment from the aspect of competitiveness}

One of the areas of increasing competitiveness of countries is policy focused on the support of increasing attractiveness of a country to foreign investors, or on

\footnotetext{
${ }^{1}$ This concept, as the basis for competitiveness, considers performance and quality of enterprises with quality of EE interpreted in interaction with macro-economic, political, legal and social framework of economic development. It is used annually for the evaluation of global competitiveness in the Global Competitiveness Reports published by the World Economic Forum.
} 
the support of acquisition of new FDI and also maintaining already adapted foreign investment companies in a country. The OECD (2008) considers FDI as a key driver of international economic integration. Together with the right policy framework FDI can provide financial stability, promote economic development and enhance the well-being of societies. Deregulation of markets, technological innovations and cheaper communication tools have allowed investors to diversify their participation in competitive markets overseas. In consequence, a significant increase in cross-border capital movements including direct investment has become a key factor in international economic integration, more generally referred to as a globalization. By the very nature of its motivation, FDI promotes stable and long-lasting economic links among countries through direct access of direct investors from home economies to production units of the host economies. FDI assists host countries in developing local enterprises, promotes international trade through access to markets and contributes to the transfer of technology and know-how. In addition to its direct effects, FDI has an impact on the development of labour and financial markets and influences other aspects of economic performance through its other spill-over effects.

Recently there has grown an importance of support increasing attractiveness of a country to foreign investors, or more precisely for attracting new FDI and also maintaining already adapted foreign investment companies in a country and especially from the perspective of increasing competitiveness among countries. At present, the FDI is a critical determinant of integration of countries into the global economy having a significant impact on effectiveness and restructuring of individual economies and transnational companies (Šestáková, 2008). In this context the literature pays adequate attention to the impact of investment incentives on volume of investments (Bolcha, Zemplinerová, 2012), and to dependence of the development of FDI on institutional changes (Globerman and Shapiro, 1998). Several studies ask for careful examination of effectiveness of investment incentives on the volume of FDI and their impact on economic growth and employment. Srholec (2004) draws attention to uncertain return of investment incentives in the form of state budget revenues and recalls the possibility of transfer prices. Lim (2001) argues that effects of investment incentives can be reduced by investors' scepticism about government commitments which may change the original decisions and as a problem he also considers different tax systems. Noteworthy is his finding that the main motives for FDI investors are conditions of infrastructure, macroeconomic stability, trade liberalization and transparency of tax laws. The evaluation of existing system of promotion of foreign investments in Slovakia, analysis of investor decisionmaking factors in placing investments and modification of existing system of investment incentives create the content of the study of EU SAV (Kučera et al., 2010). Competition among countries in attraction of FDI is multiplied especially between countries with similar level of economic development and with similar competitive advantages of the economies as the possible locations for FDI. With gradual convergence of economic level of countries and in connection with global liberalization of foreign trade and investment the importance of this 
competition is clearly increasing. Especially strong is this competition among countries in some specific sectors and also in circumstances when it attracts such foreign investor, who would have the multiplier effect on attractiveness to other investors or suppliers. Such sector is for example the automobile industry (Šestáková, 2008). The entrepreneurial environment plays an important role in decision-making process of the capital allocation of foreign investors. Its quality has an impact on development of FDI inflows to the country.

\subsection{Summary of theoretical knowledge for formulation of hypothesis}

Quality entrepreneurial environment adequately motivating country's population to perform business is generally one of the determining resources of government machinery to ensure the long-term competitiveness of national economy. The absence of conditions for effective competition among entrepreneurs means that the market mechanism is unable to work. Entrepreneurial environment does not influence only the activity of local business entities, but is also an important part of deciding of foreign investors on the allocation of their capital, or FDI into the country. FDI contributes through a variety of direct and indirect effects to development of countries and increases their competitiveness. Countries try to attract investors by improving the investment climate in a country as FDI is currently the determinant of integration of countries into the global economy and no economic theorem can be presented without the word globalization. Relations of the entrepreneurial environment, foreign direct investment and competitiveness are transparently illustrated in the following scheme (Figure 1).

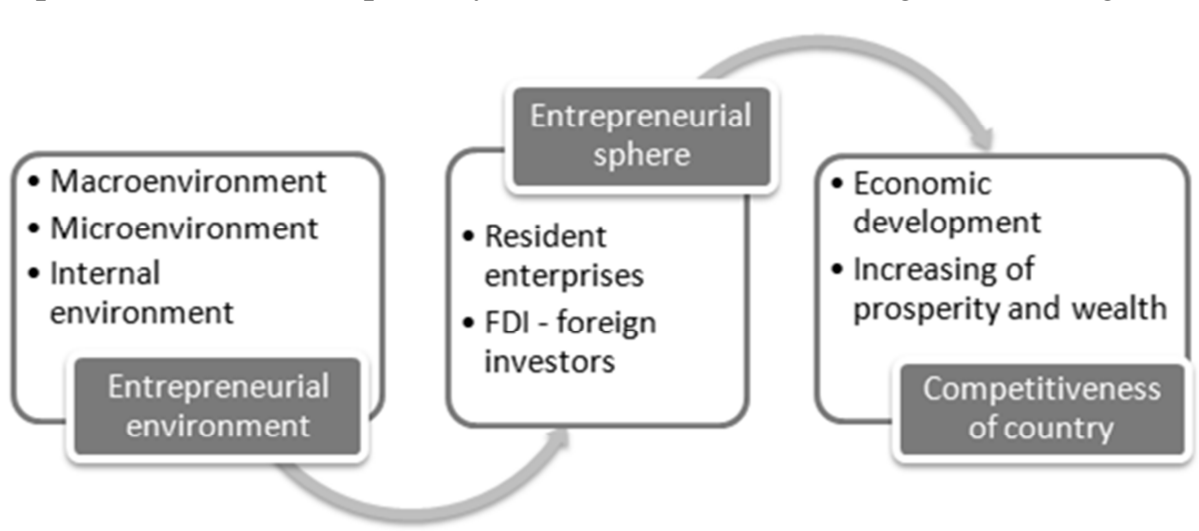

Figure 1 - Diagram of dependence "Entrepreneurial environment - FDI Competitiveness" (Source: own processing) 


\section{METHODOLOGY AND DATA}

\subsection{Identification of Barriers of the Slovak Entrepreneurial Environment}

To identify barriers of the Slovak entrepreneurial environment there were used methodology and data of the World Bank's survey - "Doing Business", primarily for comparison of Slovakia with the Visegrad Four Group: Poland, Hungary, and the Czech Republic. These countries create ideal comparative sample for Slovakia. Besides that if a foreign investor decides to invest directly in the Central Europe, it is often the Visegrad Group that will be chosen among and which entrepreneurial environment will be reflected and compared. The report "Doing Business 2012: Doing Business in a More Transparent World" assesses regulations affecting domestic firms in 183 economies and ranks the economies in 11 areas of business regulation. The last year's report data cover regulations measured from June 2010 till May 2011. Mentioned 11 areas of business regulation include: starting a business, dealing with construction permits, getting electricity, labour law, registering property, getting credit, protecting investors, paying taxes, trading across borders, enforcing contracts, and resolving insolvency (The World Bank - International Finance Corporation, 2012). Identification of barriers of the Slovak entrepreneurial environment was based on comparison of the results in each of these mentioned areas from "Doing Business". Tab. 1 offers illustrative example of comparison in the indicator "Starting a business".

Table 1 - Conditions of "Starting a business" in Slovakia and in the V4 countries

\begin{tabular}{l|r|r|r|r|r}
\hline & Slovakia & $\begin{array}{c}\text { Czech } \\
\text { Republic }\end{array}$ & Poland & Hungary & $\begin{array}{c}\text { OECD } \\
\text { average }\end{array}$ \\
\hline Rank & 76 & 138 & 126 & 39 & \\
\hline Procedures (number) & 6 & 9 & 6 & 4 & 5 \\
\hline Time (days) & 18 & 20 & 32 & 4 & 12 \\
\hline Cost (\% of income per capita) & $1.8 \%$ & $8.4 \%$ & $17.3 \%$ & $7.6 \%$ & $4.7 \%$ \\
\hline $\begin{array}{l}\text { Paid-in Min. Capital (\% of } \\
\text { income per capita) }\end{array}$ & $20.9 \%$ & $30.7 \%$ & $14.0 \%$ & $9.7 \%$ & $14.1 \%$ \\
\hline
\end{tabular}

Source: The World Bank, 2012

Table 1 shows that the Slovak Republic stands at $76^{\text {th }}$ position in the ranking of 183 economies on the ease of starting a business. Better placed is Hungary, which came on 39th place. Compared with Slovakia starting a business requires less procedures, less time and less required minimum capital in Hungary. While in Slovakia an entrepreneur must go through six procedures in 18 days, in Hungary it is only 4 procedures in only 4 days which significantly makes it easier to enter into the business. However, the Slovak entrepreneur has had less costs in 
setting up business than in Hungary - only $1.8 \%$ compared with $7.6 \%$ of GNI per capita (The World Bank, 2012).

Based on this comparison of Slovakia with the V4 countries within the framework of "Doing Business 2012" survey, there were identified key barriers of entrepreneurial environment (inspiration to improve conditions for entrepreneurs):

1) Getting electricity: To obtain a new electricity connection in the Slovak Republic high costs are required. Getting electricity in Slovakia costs $242.2 \%$ of income per capita.

2) Paying taxes: There is high administrative burden of complying with taxes in the Slovak Republic. Slovak entrepreneur has to pay up to 31 different kinds of taxes a year, pays the highest tax on wages including the various contributions, which amounts to $39.6 \%$ of profit.

3) Trading across borders: Exporting and importing of goods requires acquisition of more documents in a longer time than it is an average in the OECD countries. Also, the cost of export and import are half higher in Slovakia than in other V4 countries and the OECD.

4) Enforcing contracts: There is low efficiency of the judicial system in resolving a commercial dispute before local courts. Enforcing a contract in Slovakia costs $30.0 \%$ of the value of the claim.

5) Protecting investors: There is low rating of transparency of operations and management responsibility for decisions. In total average of the strength of investor protection index Slovakia is lagging behind, which indicates relatively weak minority shareholder's protection against directors' use of corporate assets for personal gain- or self-dealing (The World Bank, 2012).

Identified barriers of the Slovak EE will be used as variables in examination of correlation in the section 3.2.

\subsection{Study of correlation barriers of EE and FDI flows}

The aim of this part is based on analysis of entrepreneurial environment to determine attractiveness of investment climate in the country via the medium of "Doing Business" survey. The main method to achieve this goal is testing of hypotheses. Based on the goal we have established the null and alternative hypothesis:

H0: There is no statistically significant correlation between barriers of entrepreneurial environment and FDI inflow into the country.

H1: There is statistically significant correlation between barriers of entrepreneurial environment and FDI inflow into the country. 
We have tested the barriers of entrepreneurial environment that have been identified by comparing Slovakia with V4 countries within the framework of „Doing Business 2012" survey ${ }^{2}$. As a selective statistical set we have chosen the states with the highest FDI inflows which are placed in the top 25 places of FDI Confidence Index (China, India, Brazil, USA, Germany...). Investigation period was year 2011. All specifications of testing are clearly shown in the Table 2.

Table 2 - Summary of testing specifics

\begin{tabular}{|c|c|}
\hline Variables & 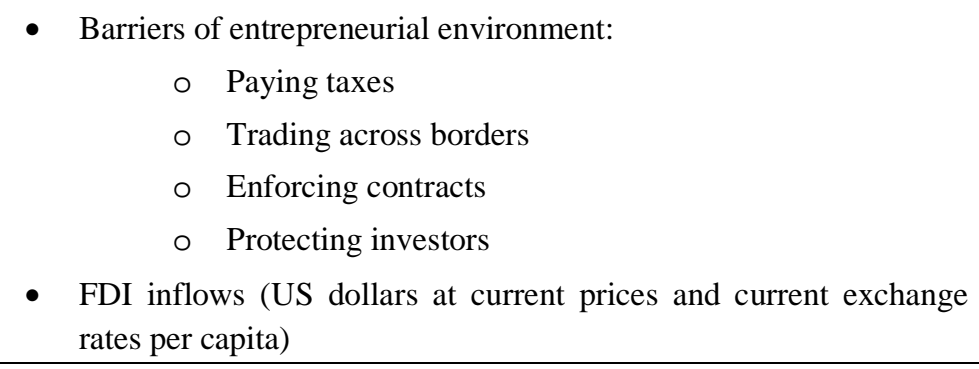 \\
\hline $\begin{array}{l}\text { Selective statistical } \\
\text { set }\end{array}$ & $\begin{array}{l}\text { Top } 25 \text { countries of FDI Confidence Index } \\
\text { Year } 2011\end{array}$ \\
\hline Test method & $\begin{array}{l}\text { Spearman's rank correlation coefficient }{ }^{3} \text {, Spearman rank correlation } \\
\text { test }^{4}\end{array}$ \\
\hline
\end{tabular}

Source: own processing

${ }^{2}$ Barrier of "Getting electricity" were omitted because of deficiency of necessary data. FDI inflows were obtained from the statistical database of United Nations Conference on Trade and Development UNCTADSTAT.

${ }^{3}$ Spearman's rank correlation coefficient $r_{s}$ is named after $\mathrm{CH}$. Spearman and indicates the strength and direction of the relationship between two variables. It can take values between $\langle-1 ; 1\rangle$. Values close to 0 mean that there is no correlation between two quantities. When $r_{s}=-1$, we have two sets of numbers that have a perfect negative correlation. Similarly an $\mathrm{r}_{\mathrm{s}}=+1$ indicates a perfect positive correlation. For a sample of size $n$ of paired variables $X$ and $Y$, the $n$ raw scores $x_{i}$ and $y_{i}$ are converted to ranks $p_{i}$ and $q_{i}$. Calculation: $r_{s}=1-\frac{6}{n\left(n^{2}-1\right)} \sum_{i=1}^{n}\left(p_{i}-q_{i}\right)^{2}$.

If we have a case that for different units are found the same values, we assign averages of serial numbers falling to them and then we use a corrected version of Spearman's rank correlation coefficient: $r_{s}=1-$ $\frac{6}{n\left(n^{2}-1\right)-c} \sum_{i=1}^{n}\left(p_{i}-q_{i}\right)^{2}$, where $c$ is correction coefficient: $c=\sum_{j=1}^{k}\left(c_{j}{ }^{3}-c_{j}\right)$, where $c_{j}$ is number of duplicating in first or second sets (Hudec, et al., 2007).

${ }^{4}$ Spearman Rank Correlation Test is known, that as testing characteristic for testing independence of two sets of variables it uses Spearman's rank correlation coefficient $r_{s}$. For a sample of size $n>10$ we can use testing characteristic $t=r_{s} \sqrt{\frac{n-2}{1-r_{s}^{2}}}$, which have approximately Student's $t$-distribution for $(n-2)$ degrees of freedom. We test the null hypothesis H0: Two sets of variables are independent. We reject null hypothesis at $\alpha=1-\gamma$ level of confidence in behalf of the alternative hypothesis H1: Two sets of variables are dependent, when testing characteristic $|t|>\frac{t_{\frac{1+\gamma}{2}}}{2}(n-2)$ (Hudec, et al., 2007). 
Illustratively are shown only results of testing of one barrier - "Protecting investors". This results and method of testing are shown in the Table 3 and Table 4.

Table 3 - Testing of correlation of barrier "Protecting investors" and FDI inflow without time difference in MS Excel

\begin{tabular}{|c|c|c|c|c|c|c|c|c|}
\hline \multicolumn{2}{|c|}{ Economy } & $\begin{array}{l}\text { INWARD } \\
\text { FDI flows }\end{array}$ & $\begin{array}{c}\text { Protecting } \\
\text { Investors - } \\
\text { Rank }\end{array}$ & Rank X & Rank Y & Di & $\mathrm{Di}^{\wedge} \mathbf{2}$ & $\mathbf{C}$ \\
\hline \multicolumn{2}{|l|}{ Australia } & $1,827.71$ & 66 & 24 & 12.5 & 11.5 & 132.25 & \\
\hline \multicolumn{2}{|l|}{ Brazil } & 338.97 & 79 & 12 & 15.5 & -3.5 & 12.25 & \\
\hline \multicolumn{2}{|l|}{ Canada } & $1,191.62$ & 4 & 23 & 2.5 & 20.5 & 420.25 & \\
\hline \multicolumn{2}{|l|}{ China } & 92.01 & 98 & 7 & 19 & -12 & 144 & \\
\hline \multicolumn{2}{|l|}{ France } & 628.72 & 79 & 17 & 15.5 & -1.5 & 2.25 & \\
\hline \multicolumn{2}{|l|}{ Germany } & 491.73 & 98 & 16 & 19 & -3 & 9 & \\
\hline \multicolumn{2}{|l|}{ India } & 25.42 & 46 & 4 & 10 & -6 & 36 & \\
\hline \multicolumn{2}{|l|}{ Indonesia } & 78.02 & 46 & 5 & 10 & -5 & 25 & \\
\hline \multicolumn{2}{|l|}{ Japan } & -13.90 & 17 & 3 & 8 & -5 & 25 & \\
\hline \multicolumn{2}{|c|}{ Rep.of Korea } & 96.32 & 79 & 8 & 15.5 & -7.5 & 56.25 & \\
\hline \multicolumn{2}{|l|}{ Malaysia } & 414.63 & 4 & 15 & 2.5 & 12.5 & 156.25 & 2 \\
\hline \multicolumn{2}{|c|}{ Netherlands } & $1,027.88$ & 124 & 22 & 22.5 & -0.5 & 0.25 & \\
\hline \multicolumn{2}{|l|}{ Poland } & 395.28 & 46 & 14 & 10 & 4 & 16 & 3 \\
\hline \multicolumn{2}{|c|}{ Russian Fed. } & 370.20 & 114 & 13 & 21 & -8 & 64 & \\
\hline \multicolumn{2}{|l|}{ Singapore } & $12,336.95$ & 2 & 25 & 1 & 24 & 576 & \\
\hline \multicolumn{2}{|c|}{ South Africa } & 115.09 & 10 & 9 & 5.5 & 3.5 & 12.25 & \\
\hline \multicolumn{2}{|l|}{ Spain } & 634.51 & 98 & 18 & 19 & -1 & 1 & 3 \\
\hline \multicolumn{2}{|l|}{ Switzerland } & -25.39 & 167 & 2 & 24.5 & -22.5 & 506.25 & \\
\hline \multicolumn{2}{|c|}{ Taiwan Pr. of China } & -84.43 & 79 & 1 & 15.5 & -14.5 & 210.25 & 4 \\
\hline \multicolumn{2}{|l|}{ Thailand } & 137.69 & 13 & 10 & 7 & 3 & 9 & \\
\hline \multicolumn{2}{|l|}{ Turkey } & 215.59 & 66 & 11 & 12.5 & -1.5 & 2.25 & 2 \\
\hline \multicolumn{2}{|c|}{ United Arab Emirates } & 973.14 & 124 & 21 & 22.5 & -1.5 & 2.25 & 2 \\
\hline \multicolumn{2}{|c|}{ United Kingdom } & 861.06 & 10 & 20 & 5.5 & 14.5 & 210.25 & \\
\hline \multicolumn{2}{|c|}{ United States } & 716.03 & 6 & 19 & 4 & 15 & 225 & \\
\hline \multicolumn{2}{|l|}{ Vietnam } & 83.68 & 167 & 6 & 24.5 & -18.5 & 342.25 & 2 \\
\hline \multicolumn{2}{|c|}{$\sum$} & & & 25 & & & $3,195.5$ & \\
\hline $\mathbf{C}$ & 132 & HO & \multicolumn{6}{|c|}{ Two sets are independent } \\
\hline Rs & -0.23953 & H1 & \multicolumn{6}{|c|}{ Two sets of variables are dependent } \\
\hline $\mathbf{T}$ & -1.18317 & We do not $r$ & reject Ho. & & & & & \\
\hline T student & 2.069 & Two sets ar & e independen & & & & & \\
\hline
\end{tabular}

Source: UNCTADSTAT; The World Bank, 2012; own calculation 
Table 4 - Examination of dependence of FDI inflow and "Protecting investors"

\begin{tabular}{|c|c|}
\hline Variable X & $\begin{array}{l}\text { FDI inflows (US dollars at current prices and current } \\
\text { exchange rates per capita) }\end{array}$ \\
\hline Variable $\mathbf{Y}$ & $\begin{array}{l}\text { Ranking of selected countries in area of Doing Business } 2012 \\
\text { - „Protecting investors“ }\end{array}$ \\
\hline Null $\mathbf{H}_{0}$ & $\begin{array}{l}\text { There is no statistically significant correlation between two } \\
\text { variables. }\end{array}$ \\
\hline Alternative $\mathbf{H}_{1}$ & $\begin{array}{l}\text { There is statistically significant correlation between two } \\
\text { variables. }\end{array}$ \\
\hline$\alpha$ - Level of confidence & All tests were performed at $\alpha=0.05$ level of confidence. \\
\hline Spearman coefficient & $r_{s}=-0.239526765$ \\
\hline Testing characteristic & $t=-1.183172442$ \\
\hline $\begin{array}{r}\text { Critical values for rejection } \\
\text { of } \mathrm{HO}\end{array}$ & $\begin{array}{l}W_{\alpha}:|t|>t_{\frac{1+\gamma}{2}}(n-2) \\
\text { While } \frac{t_{1+\gamma}}{2}(n-2)=t_{0.975}(23)=2.069 \\
1.183172442>2.069 \text { false }\end{array}$ \\
\hline Conclusion & We do not reject $\mathrm{H}_{0} »$ Two sets are INDEPENDENT. \\
\hline
\end{tabular}

Source: own calculation

The value of Spearman's rank correlation coefficient $r_{s}=-0.239526765$ (Table 3) means, that between FDI inflow in a country and values of "Protecting investors" should be negative correlation, but the value of coefficient approaches to 0 . By calculation of tested characteristic and by finding out the respective value of Student's t-distribution, we came to the inequality $|t|=1.183172442>$ $t_{\frac{1+\gamma}{2}}(n-2)=t_{0.975}(23)=2.069$. As the inequality is false, hypothesis $\mathrm{H}_{0}$ cannot be rejected and we can claim that there is no statistically significant correlation between two variables. More precisely it means that there is no sufficient proof that hypothesis $\mathrm{H}_{1}$ is valid and also that FDI inflow is dependent on ranking a country in the indicator of Doing Business - ,Protecting investors“.

\subsection{Identification of time period during which foreign direct investment is able to react to changes in its determinants}

Because it is commonly known that there is a de-synchronisation in reaction of FDI to changes in its determinants, we have tested mentioned hypothesis for two times, firstly without the time difference of FDI and secondly with time difference of FDI. Although we talk about testing hypotheses without time delay, FDI and "Doing Business" survey cannot be perfectly synchronized in time. Because "Doing Business" survey is created for the period from 1.5 to 0.5 years backwards (for example, "Doing Business 2012" is composed over the period from June 2010 to May 2011), we link indicators of "Doing Business 2012" with FDI flows in 2011. This implies that already at this testing "without time difference," we expect delays of FDI behind „Doing Business” survey for the six 
months. By testing "with time difference" we link indicators of "Doing Business 2011" with FDI flows in 2011, which means that we test how conditions of entrepreneurial environment a year and a half ago influence FDI inflow in actual period. Conclusions are shown in the Table 5.

\section{RESULTS OF TESTING AND DISCUSSION}

Results of statistical examination of correlation 4 barriers of EE and FDI inflows in the selected countries are clearly summarized in the Table 5.

Table 5 - Summary of testing results

\begin{tabular}{|c|c|}
\hline \multicolumn{2}{|c|}{ Correlation of FDI inflow and "Protecting investors" } \\
\hline Without time difference & With time difference \\
\hline$r_{s}=-0.239526765$ & $r_{s}=-0.234551108$ \\
\hline Variables are INDEPENDENT. & Variables are INDEPENDENT. \\
\hline \multicolumn{2}{|c|}{ Correlation of FDI inflow and "Paying taxes" } \\
\hline Without time difference & With time difference \\
\hline$r_{s}=-0.552307692$ & $r_{s}=-0.585802232$ \\
\hline Variables are DEPENDENT. & Variables are DEPENDENT. \\
\hline \multicolumn{2}{|c|}{ Correlation of FDI inflow and "Trading across borders" } \\
\hline Without time difference & With time difference \\
\hline$r_{s}=-0.339230769$ & $r_{s}=-0.365384615$ \\
\hline Variables are INDEPENDENT. & Variables are INDEPENDENT. \\
\hline \multicolumn{2}{|c|}{ Correlation of FDI inflow and "Enforcing contracts" } \\
\hline Without time difference & With time difference \\
\hline$r_{s}=-0.303846154$ & $r_{s}=-0.263846154$ \\
\hline Variables are INDEPENDENT. & Variables are INDEPENDENT. \\
\hline
\end{tabular}

Source: own calculation

Besides the four tested barriers of entrepreneurial environment we have identified one barrier, where was noted moderate dependence on development of FDI inflows into country with time difference of six months behind development of barriers, specifically:

- Paying taxes - moderate negative correlation

In testing time difference of a year and a half we have identified one barrier which development correlates with development of FDI inflows into country, concretely:

- Paying taxes - moderate negative correlation

These correlations mean that compared countries with other countries of the sample ranked at higher places of the "Doing Business" survey, in the framework of barriers "Paying taxes" have registered increasing FDI inflows in the same 
year (or more precisely six months later). Consequently, a positive change of entrepreneurial environment within the mentioned barrier can increase inflow of FDI and thereby it increases attractiveness of investment climate in a country.

By testing selected sample first without and secondly with time delay of FDI behind period of evaluation of "Doing Business" survey, this paper has found that positive change of tested barrier of entrepreneurial environment - "Paying taxes" can be reflected in FDI inflow already during six months after the change. In the same barrier there was confirmed correlation also in a year and a half. This barrier appears to be most relevant for foreign investors.

\section{CONCLUSION}

The business environment is an important factor of FDI flows. In this area, on the one hand, the trend of removing barriers and improving conditions to foreign investors continues (opening of protected sectors, liberalization, and privatization) followed by FDI promotion (fiscal and financial incentives to promote FDI). On the other hand, there are increasingly being promoted trends towards greater regulation, respectively determination of FDI in particular states taking into consideration a number of aspects - from environmental protection to strategic interests (raw materials, production or strategic sectors). Specific response after the 2010 has been nationalization of the companies in key sectors (Žd'árek, 2010).

It is known, that high dependency of the Slovak Republic on industries which cannot be provided by itself but are dependent on foreign investors predetermines Slovakia to negotiate with investors, constantly monitor investment climate development and make compromises and frequent exceptions. The main determinant of attractiveness for FDI (investment environment) is exactly EE. Therefore, barriers of EE are the factor which investors take into consideration when selecting an investment location. In the light of mentioned context we attempted, in this paper, to identify barriers of EE, which the government should focus on by improving business conditions. Based on comparison with the V4 countries we have selected following key barriers of the Slovak EE: a) getting electricity, b) paying taxes, c) trading across borders, d) enforcing contracts, and e) protecting investors. After testing correlation of identified barriers with development of FDI by Spearman's rank correlation coefficient we confirmed significance especially one of five identified barriers - paying taxes. This barrier appears to be most binding for foreign investors. This knowledge could be relevant for Slovak legislature and those who have competence to improve EE. To reduce barriers of EE, especially in the interaction with FDI, the government should be aware of the opposite extreme to find out the real boundary, where removing barriers brings benefits in the form of FDI inflow, its direct and indirect effects, and where it is already beginning to discriminate domestic entrepreneurs pushing them out of the domestic market and reducing their competitiveness. 


\section{REFERENCES}

Bolcha, P., \& Zemplinerová, A., 2012. Dopad investičních pobídek na objem investic v České republice, in Politická ekonomie, 1/2012, pp. 81 -100.

Chi, T., Kilduff, P. P. D., \& Gargeya, V. B., 2009. Alignment between business environment characteristics, competitive priorities, supply chain structures, and firm business performance, in International Journal of Productivity and Performance Management, Vol. 58, issue 7, pp. 645-669, retrieved from <http://www.emeraldinsight.com/1741-0401.htm>.

Dess, G. G., \& Beard, D. W., 1984. Dimensions of organizational task environments, in Administrative Science Quarterly, 29, 1, pp. 52-73.

Folkerts, H., \& Koehorst, H., 1998. Challenges in international food supply chains: vertical coordination in the European agribusiness and food industries, in British Food Journal, 100, 8, pp. 385-388.

Frolich, M., \& Westbrook, R., 2001. Arcs of integration: an international study of supply chain strategies, in Journal of Operations Management, 2001, 19, pp. 185-200.

Globerman, S., \& Shapiro, D. M., 1998. The Impact of Government Policies on Foreign Direct Investment. The Canadian Experience, in Journal of International Business Studies, 30, 3, pp. 513-532.

Hobbs, J., \& Young, L., 2000. Closer coordination in agrifood supply chains: a conceptual framework and some preliminary evidence, in Supply Chain Management, 5, 3, pp.131-142.

Hudec, O., Sisáková, J., Tartal'ová, A., \& Želinský, T., 2007. Štatistické metódy v ekonomických vedách, Košice, Technická univerzita v Košiciach, Ekonomická fakulta.

Kučera, M., Hošoff, B., Hvozdíková, V., Jašsová, K., \& Kadlic, T., 2010. Analýza nástrojov štátu pri podpore zahraničných investícií a návrh ich optimalizácie. Expertízna štúdia EÚ SAV, retrieved from <http://www.ekonom.sav.sk/uploads/journals/ES08.pdf>.

Kuzmišinová, V., 2009. Podniky - univerzity - samospráva (regióny) (1. ed.) Košice, Technická univerzita v Košiciach, Ekonomická fakulta.

Lim, E. G., 2001. Determinants of, and Relation Between, Foreign Direct Investment and Growth. A Summary of the Recent Literature, IMF Working Papers WP/01/175, Washington, DC, International Monetary Fund.

Lindgreen, A., \& Hingley, M., 2003. The impact of food safety and animal welfare policies on supply chain management: the case of Tesco meat supply chain, in British Food Journal, 105, 6, pp. 328-349. 
Organisation For Economic Co-Operation And Development, 2008. OECD Benchmark Definition of Foreign Direct Investment (4th ed.), retrieved from http://www.oecd.org/dataoecd/26/50/40193734.pdf.

Rademakers, M., \& Knight, P., 1998. Concentration and inter-firm cooperation within the Dutch potato supply chain, in Supply Chain Management, 3, 4, pp. 203-213.

Šestáková, M., 2008. Konkurencia medzi štátmi v oblasti získavania a udržania zahraničných investícií, in Working Papers EÚ SAV, 11, Bratislava, Ekonomický ústav SAV, $60 \mathrm{p}$, retrieved from <http://www.ekonom.sav.sk/uploads/journals/WP11.pdf>.

Srholec, M., 2004. Př́mé zahraniční investice v České republice (1. ed.), Praha, Linde.

The World Bank \& International Finance Corporation, 2012. Doing Business 2012: Doing Business in a More Transparent World, Washington D.C., International Bank for Reconstruction and Development, The World Bank. Retrieved from

$<$ http://www.doingbusiness.org/ /media/FPDKM/Doing\%20Business/Document s/Annua 1 - Reports/English/DB12-FullReport.pdf>.

The World Bank Group, 2012. Doing Business: Measuring Business regulations: Historical Data Sets and Trends Data. The World Bank, retrieved from $<$ http://www.doingbusiness.org/customquery>.

Unctadstat, 2012. Unctadstat Reports, retrieved from

http://unctadstat.unctad.org/ReportFolders/reportFolders.aspx.

Viturka, M., 2005. Hodnocení regionální kvality podnikatelského prostredí z pohledu inovačního potenciálu, retrieved from

$<$ http://www.cers.tuke.sk/cers2005/doc/Viturka.pdf>.

Ward, P. T., Duray, R., Leong, G. K., \& Sum, C., 1995. Business environment, operations strategy, and performance: an empirical study of Singapore manufacturers, in Journal of Operations Management, 13, pp. 99-115.

Wilson, T., \& Clarke, W., 1998. Food safety and traceability in the agricultural supply chain: using the internet to deliver traceability, in Supply Chain Management, 3,3, pp. $127-133$.

Zhan, J., 2013. World Investment Report 2013: Global Value Chains: Investment and Trade for Development. Statement. Retrieved from <http://unctad.org/Sections/dite_dir/docs/diae_stat_2013-06-26_en.pdf>.

Žd’árek, V., 2010. Mezinárodní pohyb kapitálu v roce 2010 a environmentální investice, in Ekonomické listy, 4. 


\section{ABOUT THE AUTHORS}

Doc. Ing. Peter Kuzmišin, DrSc., Assoc. Professor, Technical University of Košice, Faculty of Economics, Department of Economic Theories, Němcovej 32, 040 01, Košice, Slovakia, e-mail: peter.kuzmisin @ tuke.sk.

Ing. Alžbeta Šišková, graduate, Technical University of Košice, Faculty of Economics, Němcovej 32, 040 01, Košice, Slovakia, e-mail: betkasis@gmail.com. 